\title{
Article
}

\section{Oral Mucosa Could Be an Infectious Target of SARS-CoV-2}

\author{
Tatsuo Okui, Yuhei Matsuda (D), Masaaki Karino, Katsumi Hideshima and Takahiro Kanno * \\ Department of Oral and Maxillofacial Surgery, Shimane University Faculty of Medicine, \\ Izumo 693-8501, Shimane, Japan; tokui@med.shimane-u.ac.jp (T.O.); yuhei@med.shimane-u.ac.jp (Y.M.); \\ karino71@med.shimane-u.ac.jp (M.K.); hideg@med.shimane-u.ac.jp (K.H.) \\ * Correspondence: tkanno@med.shimane-u.ac.jp; Tel.: +81-(0)853-20-2301; Fax: +81-(0)853-20-2299
}

check for updates

Citation: Okui, T.; Matsuda, Y.; Karino, M.; Hideshima, K.; Kanno, T. Oral Mucosa Could Be an Infectious Target of SARS-CoV-2. Healthcare 2021, 9, 1068. https://doi.org/ 10.3390/healthcare 9081068

Academic Editors: Rahman Shiri and Jitendra Singh

Received: 6 June 2021

Accepted: 17 August 2021

Published: 19 August 2021

Publisher's Note: MDPI stays neutral with regard to jurisdictional claims in published maps and institutional affiliations.

Copyright: (C) 2021 by the authors. Licensee MDPI, Basel, Switzerland. This article is an open access article distributed under the terms and conditions of the Creative Commons Attribution (CC BY) license (https:/ / creativecommons.org/licenses/by/ $4.0 /)$.

\begin{abstract}
The World Health Organization reported that severe acute respiratory syndrome coronavirus 2 (SARS-CoV-2) transmission is caused by respiratory droplets and aerosols from the oral cavity of infected patients. The angiotensin-converting enzyme 2 (ACE2) is considered the host functional protein for SARS-CoV-2 infection. In this article, we first revealed that the positive proportion of ACE2 expression in gingival cells collected from the gingival sulcus was increased to the same level as the tongue. Our data demonstrate that cells in the gingival sulcus may be a new entry point for the SARS-CoV-2 virus via a high expression of ACE2. In addition, we first evaluated the expression of ACE2 in various sites of the oral cavity with noninvasive, convenient liquid-based cytology. The liquid-based cytology evaluation of oral tissue may provide a novel preventive medical avenue against COVID-19.
\end{abstract}

Keywords: COVID-19; ACE2 expression in oral region; liquid-based cytology

\section{Introduction}

Coronavirus infectious disease 2019 (COVID-19) caused by severe acute respiratory syndrome coronavirus 2 (SARS-CoV-2) spread worldwide during the years 2019 to 2021 [1]. The primary entry of SARS-CoV-2 is considered to be the contact between projected droplets and cells in the oral cavity, nose or eyes [2]. Although SARS-CoV-2 can be detected in saliva, the routes of infection remain elusive, and little is known about the routes of transmission through the oral mucosa [3]. Additional clinical evidence and pathological research are thus needed to confirm the ability of SARS-CoV-2 to infect the oral tissues. A recent study of SARS-CoV-2 host cell receptor angiotensin-converting enzyme 2 (ACE2) could be valuable for the prevention and treatment of COVID-19 [4].

The infectivity of SARS-CoV-2 depends on the ability of this virus to enter the host cells, and there is clear evidence that ACE2 is the primary receptor interacting with the virus spike protein when the SASRS-CoV-2 enters cells [5,6]. The results of a recent investigation indicated that ACE2 is expressed in oral tissues and that the oral cavity can thereby be an important reservoir of SARS-CoV-2 that may serve as an entry point to the respiratory and gastrointestinal tracts [5]. The ACE2-expressing cells in oral tissues might be a direct infection route for SARS-CoV-2 [7]. However, the distribution of AEC2 in oral tissues is still unknown. Notably, olfactory and gustatory disorders are the major frequent symptoms of COVID-19.

This article provides the first report on ACE2 expression in human oral tissue, the tongue, gingiva, and palate observed by a noninvasive, convenient and common diagnostic procedure for the oral mucosal legions, i.e., oral liquid-based cytology [8]. The protocol of this study was approved by the Research Ethics Committee of Shimane University (approval no. 20200423-2) and complies with the 1964 Helsinki Declaration and its later amendments or comparable ethical standards. 


\section{Materials and Methods}

In total, 20 volunteers (10 males and 10 females) were enrolled in the study, and their characteristics are shown in Table 1 . The median age was 36 years. Background characteristics included age, sex, smoking and alcohol consumption.

Table 1. Demographic data $(n=20)$.

\begin{tabular}{|c|c|c|}
\hline Item & Category & N $(\%)$ or Median (Range) \\
\hline \multirow{3}{*}{ Age } & Total & $36.0(29-43)$ \\
\hline & Low group $(n=9)$ & $29.0(26.0-30.5)$ \\
\hline & High group $(\mathrm{n}=11)$ & $43.0(38.0-55.0)$ \\
\hline \multirow{2}{*}{ Gender } & Male & $10.0(50.0 \%)$ \\
\hline & Female & $10.0(50.0 \%)$ \\
\hline \multirow{6}{*}{ Medical history } & Hyperuricemia & $1.0(5.0 \%)$ \\
\hline & Dermatitis & $2.0(10.0 \%)$ \\
\hline & Hypertension & $1.0(5.0 \%)$ \\
\hline & Graves' disease & $1.0(5.0 \%)$ \\
\hline & Glaucoma & $1.0(5.0 \%)$ \\
\hline & Asthma & $1.0(5.0 \%)$ \\
\hline \multirow{6}{*}{ Regular medicine } & Benzbromarone & $1.0(5.0 \%)$ \\
\hline & Minocycline & $1.0(5.0 \%)$ \\
\hline & Amlodipine & $1.0(5.0 \%)$ \\
\hline & Drospirenone & $1.0(5.0 \%)$ \\
\hline & Mercazole & $1.0(5.0 \%)$ \\
\hline & Antihistamine & $1.0(5.0 \%)$ \\
\hline \multirow{2}{*}{ Alcohol consumption } & Regular drinkers & $5.0(25.0 \%)$ \\
\hline & None or Social drinkers & $15.0(75.0 \%)$ \\
\hline \multirow{2}{*}{ Smoking history } & Yes & $5.0(25.0 \%)$ \\
\hline & No & $15.0(75.0 \%)$ \\
\hline \multirow{3}{*}{ Brinkman Index } & Total & $0.0(0.0-7.5)$ \\
\hline & Low group $(n=15)$ & $0.0(0.0)$ \\
\hline & High group $(n=5)$ & $30.0(14.0-375.0)$ \\
\hline
\end{tabular}

The preparation procedure for liquid-based cytology differs from that of the conventional preparation of brush cytology [9]. In the conventional preparation, multiple exfoliated cells are spread out on multiple glass slides immediately after the collection of the cells. The advantages of liquid-based cytology are that there were fewer air-dried artefacts and less contamination with imprecise elements such as blood or debris. We obtained cells from the tongue, palate and gingival sulcus of each subject with liquid-based cytology methods. The procedure of smear collection was carried out using the Orcellex brush (Rovers Medical Devices BV., Oss, The Netherlands). The smear specimens were made in a liquid-based Pap test (Becton, Dickinson and Company, Franklin Lakes, NJ, USA). The preparation of the samples followed the instructions for SurePath ${ }^{\mathrm{TM}}$ preparations. Cells were transferred into a settling chamber on the slide where gravitational force leads to the different sedimentations of the cells. Slides were incubated with ACE2 antibodies (protein tech, Rosemont, IL, USA. 1:6000) overnight at $4{ }^{\circ} \mathrm{C}$, followed by Histofine simple stain MAX PO (Nichirei, Tokyo, Japan.) for 20 min at room temperature as a secondary antibody. After being stained with DAB, nuclei were counterstained with Mayer's Hematoxylin 
Solution. All cells were classified as either ACE2-negative or -positive cells by three experts in cytology in the Department of Pathology, Shimane University Faculty of Medicine. Human and mouse kidney tissues (US biomax \#KDN242, Derwood, MD, USA) were used as positive and negative controls for antibody validation (Figure 1E-G).

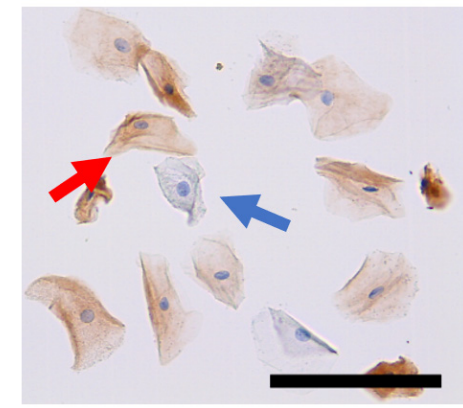

(A)

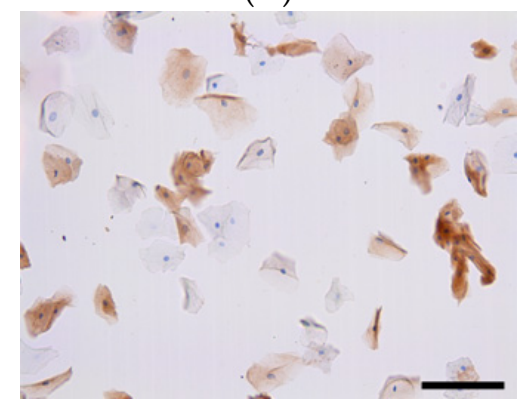

(D)

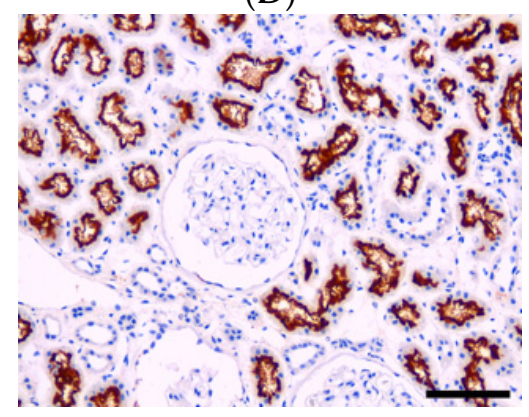

(G)

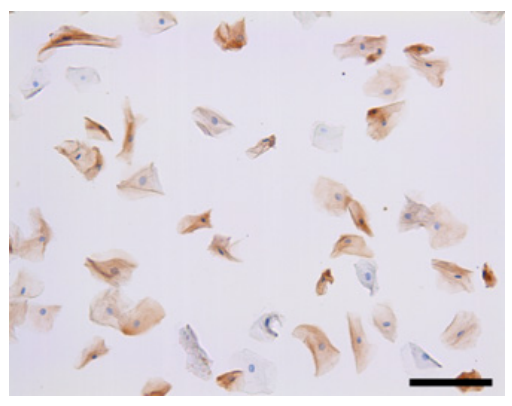

(B)

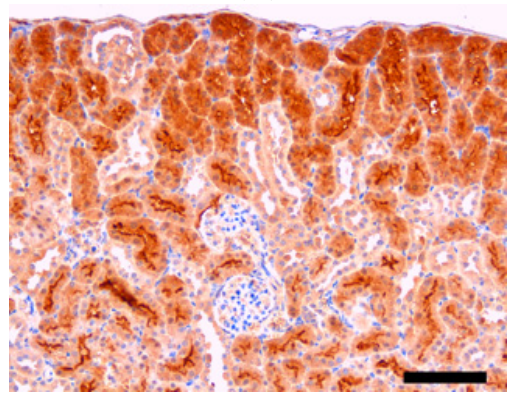

(E)

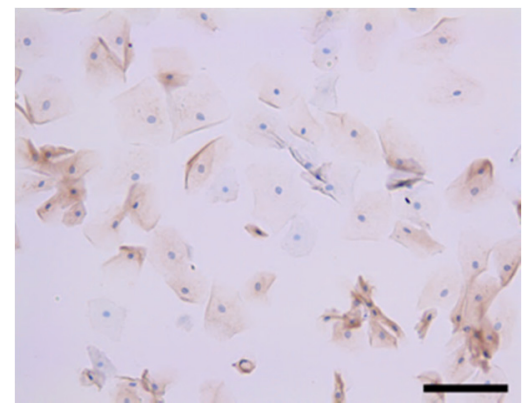

(C)

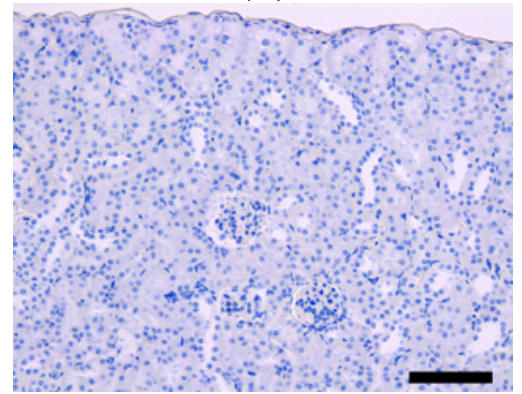

(F)

Figure 1. (A) Typical case of ACE2-positive and -negative cells. Blue arrow: ACE2-negative cell. Red arrow: ACE2-positive cell. Bar $=100 \mu \mathrm{m}$. (B) Representative ACE2 expression in tongue cells (bar $=100 \mu \mathrm{m})$. (C) Representative ACE2 expression in palate cells (bar $=100 \mu \mathrm{m}$ ). (D) Representative ACE2 expression in gingival sulcus cells (bar $=100 \mu \mathrm{m}$ ). (E) Positive control using mouse kidney. (bar $=100 \mu \mathrm{m})$. (F) Negative control using mouse kidney without the 1st antibody $($ bar $=100 \mu \mathrm{m})$. (G) Positive control using human kidney sample (bar $=100 \mu \mathrm{m})$.

All cells are classified into ACE2-positive and -negative categories by using the positive and negative control as an index. For estimating the proportion, the number of ACE2positive cells was divided by the total number of cells. ACE2 expression was compared using the Mann-Whitney $U$ test for each of the background factors. Age was divided into two groups according to median age, and the Brinkman index (number of cigarettes per day $\times$ years smoked) was divided into two groups according to 0 or more than 0 . The significance level was set at $5 \%$. All analyses were performed with the statistical software package IBM SPSS Statistics Version 26.0 (IBM Co., Armonk, NY, USA). 


\section{Results}

Twenty participants were enrolled in this study. The median (range) of age was 36.0 (29.3-43.8) and the sex was 10 males and 10 females. We collected the medical history and any regular medicine(s); however, no one used the ACE2 inhibitor. Five volunteers (25\%) were past smokers and five $(25.0 \%)$ were regular drinkers (Table 1$)$.

The ACE2 expression values were as follows: tongue, $18.2 \%$; palate, $2.0 \%$; and gingiva, $14.6 \%$. (Table 2) (Figure 1B-D). The ACE2 positivity proportions in the tongue and gingiva were significantly increased compared with that in the palate. Sex, smoking and alcohol consumption were not associated with ACE2 values in the tongue, palate and gingiva (Table 1). There was no significant correlation between age, brinkman index and ACE expression in each cite (Table 3 ).

In the site-specific cytology, the median (IQR) number of cells collected in the tongue was 2129.0 (1695.0-7497.0), of which the median (IQR) number of ACE2-receptor-positive cells was 478.0 (144.3-1051.0), and the median (IQR) ACE2-receptor-positive proportion in the tongue was $18.2(8.7-25.1)$. The median (IQR) number of cells collected in the palate was 2597.5 (1555.8-4029.5), of which the median (IQR) number of ACE2-receptor-positive cells was 44.5 (14.5-107.5), and the median (IQR) ACE2-receptor-positive proportion in the tongue was $2.0(0.9-2.7)$. The median (IQR) number of cells collected in the gingiva was 7923.5 (5457.0-14661.8), of which the median (IQR) number of ACE2-receptor-positive cells was 1323.5 (629.0-2272.3), and the median (IQR) ACE2-receptor-positive proportion in the tongue was 14.6 (7.7-20.6) (Table 2).

The analysis of variance conducted using the Friedman test showed a significant difference of $p<0.01$, and the Wilcoxon signed-rank test as the subsequent test showed a statistically significant difference between palate and tongue and between palate and gingiva $(p<0.05)$. No statistically significant difference was found between tongue and gingiva (Figure 2).

Regarding the comparison of ACE2-receptor-positive proportions by background factors of the participants, there were no statistically significant differences in gender, alcohol consumption, or smoking history in the tongue. Comparison of the ACE2-receptorpositive proportion in the palate also showed no statistically significant difference in each factor. In addition, no statistically significant difference was observed in the comparison of ACE2-receptor-positive proportion in the gingiva (Table 3).

Table 2. Result of cytology $(\mathrm{n}=20)$.

\begin{tabular}{|c|c|c|}
\hline Item & Category & Median (IQR) \\
\hline \multirow{4}{*}{ Tongue } & Total amount of cells & $2129.0(1695.0-7497.0)$ \\
\hline & ACE2 receptor negative & $993.0(556.0-1864.3)$ \\
\hline & ACE2 receptor positive & $478.0(144.3-1051.0)$ \\
\hline & Positive proportion (\%) & $18.2(8.7-25.1)$ \\
\hline \multirow{4}{*}{ Palate } & Total amount of cells & 2597.5 (1555.8-4029.5) \\
\hline & ACE2 receptor negative & $1498.0(879.0-2120.0)$ \\
\hline & ACE2 receptor positive & $44.5(14.5-107.5)$ \\
\hline & Positive proportion (\%) & $2.0(0.9-2.7)$ \\
\hline \multirow{4}{*}{ Gingiva } & Total amount of cells & $7923.5(5457.0-14,661.8)$ \\
\hline & ACE2 receptor negative & $2984.0(1208.3-4715.0)$ \\
\hline & ACE2 receptor positive & $1323.5(629.0-2272.3)$ \\
\hline & Positive proportion (\%) & $14.6(7.7-20.6)$ \\
\hline
\end{tabular}

IQR: interquartile range. 
Table 3. Comparison between groups using Mann-Whitney U test $(n=20)$.

\begin{tabular}{|c|c|c|c|}
\hline Item & Category & Median (IQR) & $p$-Value \\
\hline \multicolumn{4}{|c|}{ ACE2-receptor-positive proportion of tongue } \\
\hline \multirow{2}{*}{ Age } & Low group & $17.7(11.0-29.1)$ & \multirow{2}{*}{0.50} \\
\hline & High group & $18.7(7.7-24.5)$ & \\
\hline \multirow{2}{*}{ Gender } & Male & $11.2(6.7-23.1)$ & \multirow{2}{*}{0.14} \\
\hline & Female & $19.6(14.5-28.2)$ & \\
\hline \multirow{2}{*}{ Alcohol consumption } & Regular drinkers & $18.7(6.8-25.3)$ & \multirow{2}{*}{1.00} \\
\hline & None or Social drinkers & $17.7(8.6-25.4)$ & \\
\hline \multirow{2}{*}{ Smoking history } & Yes & $25.4(14.0-29.1)$ & \multirow{2}{*}{0.14} \\
\hline & No & $16.2(7.7-22.4)$ & \\
\hline \multirow{2}{*}{ Brinkman index } & Low group & $16.2(7.7-22.4)$ & \multirow{2}{*}{0.14} \\
\hline & High group & $25.4(14.0-29.1)$ & \\
\hline \multicolumn{4}{|c|}{ ACE2-receptor-positive proportion of Palate } \\
\hline \multirow{2}{*}{ Age } & Low group & $1.9(0.9-3.6)$ & \multirow{2}{*}{0.94} \\
\hline & High group & $2.2(0.9-2.7)$ & \\
\hline \multirow{2}{*}{ Gender } & Male & $1.6(0.9-2.2)$ & \multirow{2}{*}{0.19} \\
\hline & Female & $2.6(1.1-3.2)$ & \\
\hline \multirow{2}{*}{ Alcohol consumption } & Regular drinkers & $2.5(2.1-3.0)$ & \multirow{2}{*}{0.17} \\
\hline & None or Social drinkers & $1.4(0.8-2.7)$ & \\
\hline \multirow{2}{*}{ Smoking history } & Yes & $2.2(1.7-2.5)$ & \multirow{2}{*}{0.80} \\
\hline & No & $1.8(0.8-3.2)$ & \\
\hline \multirow{2}{*}{ Brinkman index } & Low group & $1.8(0.8-3.2)$ & \multirow{2}{*}{0.80} \\
\hline & High group & $2.2(1.7-2.5)$ & \\
\hline \multicolumn{4}{|c|}{ ACE2-receptor-positive proportion of Gingiva } \\
\hline \multirow{2}{*}{ Age } & Low group & $17.1(11.8-20.1)$ & \multirow{2}{*}{0.30} \\
\hline & High group & $11.9(3.7-22.5)$ & \\
\hline \multirow{2}{*}{ Gender } & Male & $15.6(8.1-20.1)$ & \multirow{2}{*}{0.91} \\
\hline & Female & $13.9(6.4-23.5)$ & \\
\hline \multirow{2}{*}{ Alcohol consumption } & Regular drinkers & $11.9(6.6-38.2)$ & \multirow{2}{*}{0.87} \\
\hline & None or Social drinkers & $15.2(8.9-19.2)$ & \\
\hline \multirow{2}{*}{ Smoking history } & Yes & $21.0(10.0-33.9)$ & ברת \\
\hline & No & $12.6(7.3-19.2)$ & 0.23 \\
\hline & Low group & $12.6(7.3-19.2)$ & \\
\hline Drmkman index & High group & $21.0(10.0-33.9)$ & 0.23 \\
\hline
\end{tabular}




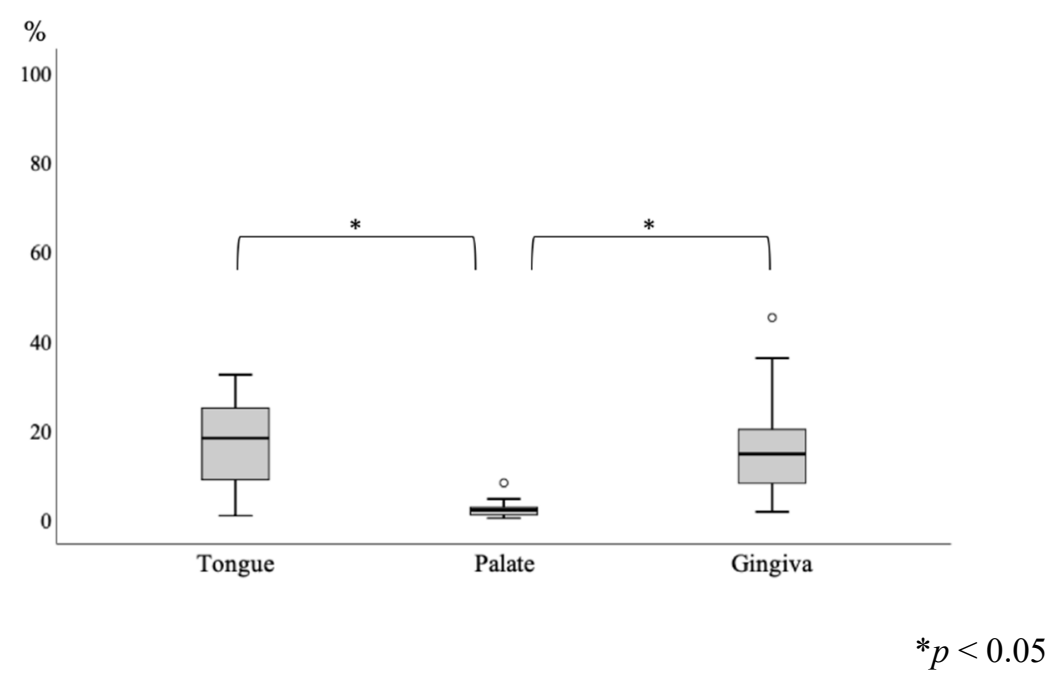

Figure 2. Comparison of positive proportion between groups of cytology site $(\mathrm{n}=20)$. (Friedman test $(p<0.01)$ and Wilcoxon signed-rank test.)

\section{Discussion}

COVID-19 infection causes several clinical forms ranging from dysgeusia and dysosmia to severe multiple organ failure and death. In most cases of COVID-19, dysgeusia and dysosmia may occur before pulmonary manifestations [10]. Several hypotheses can be considered potential explanations of this phenomenon. There is quantified evidence that SAES-CoV-2 affects the central and peripheral nervous systems. SARS-CoV-2 invades the central nervous system, but it rarely causes encephalitis or meningitis [11]. However, the onset of COVID-19 in almost 70\% of the patients involves dysgeusia and dysosmia, and central nervous system damage is unlikely to be the source of dysgeusia and dysosmia [12]. SARS-CoV-2 invades the peripheral nerves and nociceptors, as do other viruses. Urata recently reported that the olfactory epithelium (which expresses ACE2) is sloughed off for a long time after SARS-CoV-2 infection [13]. Similar to dysosmia, the most reasonable explanation of dysgeusia may be that it is a direct effect of SARS-CoV-2 on the taste buds on the tongue. In a mouse model, ACE2 does not express at the taste buds [14]. There is little knowledge of the localization of ACE2 in human taste buds. In agreement with this, the dominant expression of ACE2 in oral tissue was reported in the salivary glands and tongue compared to the gingiva and alternative sites $[15,16]$. According to the first half of a 2020 study, the distribution of the SARS-CoV-2 virus in the human oral cavity was thought to be in saliva [17]. However, more recent research revealed that the distribution of SARS-CoV-2 in effusion from the gingival sulcus is significantly increased, the same as in the saliva, tongue or nasal cavity [3]. In some research, it was reported that the occurrence of oral signs and symptoms should be considered in COVID-19 patients, including tongue ulcer, candidiasis, bleeding, HSV-1 infection, geographical tongue, and thrush-like ulcers [18]. Santos indicated that ACE2 activity is stimulated by gingivitis of the periodontitis site [19]. This symptom is thought to have a relation with ACE2 expression in oral tissue and COVID-19 virus proliferation. These findings may show that dental periodontal treatment decreases the infectivity of COVID-19 virus through oral mucosa.

Interestingly, smoking history tended to increase the expression of ACE2 in oral cavity cells. However, this study was merely a preliminary evaluation with a small number of samples. A future evaluation with a larger number of samples may provide more definitive evidence that alcohol use or smoking increases the expression of ACE2 in the oral cavity.

The present analysis first revealed that the positive proportion of ACE2 expression in gingival cells collected from the gingival sulcus was increased to the same level as the tongue. Inflammatory cytokines from periodontal pathogens in the gingival sulcus may modulate ACE2 and other SARS-CoV-2 entry proteins. Our data demonstrate that cells in the gingival sulcus may be a new entry point for the SARS-CoV-2 virus via a high 
expression of ACE2. In the present research, we first evaluated the expression of ACE2 in various sites of the oral cavity with noninvasive, convenient liquid-based cytology [9]. A recent study suggested that structural variations in human ACE2 may influence its binding with the SARS-CoV-2 spike protein [20]. Oral cavity cells clinically collected by noninvasive liquid-based cytology methods can be easily analyzed with other proteomic approaches, such as single-cell mass spectrometry or cryo-electron microscopy analysis [21,22].

These analyses can quantify the expression and structure of ACE2 and other possible markers, such as TMPRS2 $[23,24]$, through all oral, head and neck areas of an entire population, and thus a liquid-based cytology evaluation of oral tissue may provide a novel preventive medical avenue against COVID-19.

The impact of the COVID-19 pandemic restricts the daily dental treatment of patients. Our present findings indicate that the inflammatory gingival sulcus is a novel shedding route of SARS-CoV-2. Special periodontal treatment by dental professionals at a dental office may decrease the expression of ACE- 2 in the gingival sulcus cells, thereby preventing SARS-CoV-2 viral attachment and penetration via ACE-2 protein.

\section{Conclusions}

ACE2 expression is still not fully understood, including ACE2 expression in the human oral cavity and its variation among different races [25]. Liquid-based cytology is an easy, useful and noninvasive method to evaluate these important clinical topics. The liquid-based cytology evaluation of oral tissue may provide a novel preventive medical avenue against COVID-19.

Author Contributions: Conceptualization, T.O. and T.K.; methodology, T.O., T.K. and Y.M.; software, T.O., Y.M. and M.K.; validation, K.H., Y.M.; formal analysis, T.O. and Y.M.; investigation, K.H., T.O.; resources, T.K.; data curation, T.O., Y.M., M.K., K.H.; writing-original draft preparation, T.O., T.K.; writing-review and editing, T.O., T.K.; visualization, T.O.; supervision, T.K.; project administration, T.O. and T.K.; funding acquisition, T.K. All authors have read and agreed to the published version of the manuscript.

Funding: This research received no external funding.

Institutional Review Board Statement: The protocol of this study was approved by the Research Ethics Committee of Shimane University (approval no. 20200423-2) and complies with the 1964 Helsinki Declaration and its later amendments or comparable ethical standards.

Informed Consent Statement: Informed consent was obtained from all subjects involved in the study.

Data Availability Statement: All data were corrected in this research. Derived data supporting the findings of this study are available from the author (T.O.) on request.

Conflicts of Interest: The authors declare no conflict of interest.

\section{References}

1. Wang, C.; Horby, P.W.; Hayden, F.G.; Gao, G.F. A novel coronavirus outbreak of global health concern. Lancet 2020, 395, 470-473. [CrossRef]

2. Takahashi, Y.; Watanabe, N.; Kamio, N.; Kobayashi, R.; Iinuma, T.; Imai, K. Aspiration of periodontopathic bacteria due to poor oral hygiene potentially contributes to the aggravation of COVID-19. J. Oral Sci. 2020, 63, 1-3. [CrossRef]

3. Gupta, S.; Mohindra, R.; Chauhan, P.K.; Singla, V.; Goyal, K.; Sahni, V.; Gaur, R.; Verma, D.K.; Ghosh, A.; Soni, R.K.; et al. SARS-CoV-2 Detection in Gingival Crevicular Fluid. J. Dent. Res. 2021, 100, 187-193. [CrossRef]

4. Xu, H.; Zhong, L.; Deng, J.; Peng, J.; Dan, H.; Zeng, X.; Li, T.; Chen, Q. High expression of ACE2 receptor of 2019-nCoV on the epithelial cells of oral mucosa. Int. J. Oral Sci. 2020, 12, 8. [CrossRef]

5. Xiang, Z.; Koo, H.; Chen, Q.; Zhou, X.; Liu, Y.; Simon-Soro, A. Potential implications of SARS-CoV-2 oral infection in the host microbiota. J. Oral Microbiol. 2020, 13, 1853451. [CrossRef]

6. Sakaguchi, W.; Kubota, N.; Shimizu, T.; Saruta, J.; Fuchida, S.; Kawata, A.; Yamamoto, Y.; Sugimoto, M.; Yakeishi, M.; Tsukinoki, K. Existence of SARS-CoV-2 Entry Molecules in the Oral Cavity. Int. J. Mol. Sci. 2020, 21, 6000. [CrossRef]

7. Huang, N.; Pérez, P.; Kato, T.; Mikami, Y.; Okuda, K.; Gilmore, R.C.; Conde, C.D.; Gasmi, B.; Stein, S.; Beach, M.; et al. SARS-CoV-2 infection of the oral cavity and saliva. Nat. Med. 2021, 27, 892-903. [CrossRef] 
8. Hayama, F.H.; Motta, A.C.; Silva Ade, P.; Migliari, D.A. Liquid-based preparations versus conventional cytology: Specimen adequacy and diagnostic agreement in oral lesions. Med. Oral Patol. Oral Cir. Bucal 2005, 10, 115-122. [PubMed]

9. Deuerling, L.; Gaida, K.; Neumann, H.; Remmerbach, T.W. Evaluation of the Accuracy of Liquid-Based Oral Brush Cytology in Screening for Oral Squamous Cell Carcinoma. Cancers 2019, 11, 1813. [CrossRef] [PubMed]

10. Lao, W.P.; Imam, S.A.; Nguyen, S.A. Anosmia, hyposmia, and dysgeusia as indicators for positive SARS-CoV-2 infection. World J Otorhinolaryngol. Head Neck Surg. 2020, 6 (Suppl. 1), S22-S25. [CrossRef] [PubMed]

11. Meinhardt, J.; Radke, J.; Dittmayer, C.; Franz, J.; Thomas, C.; Mothes, R.; Laue, M.; Schneider, J.; Brünink, S.; Greuel, S.; et al. Olfactory transmucosal SARS-CoV-2 invasion as a port of central nervous system entry in individuals with COVID-19. Nat. Neurosci. 2021, 24, 168-175. [CrossRef]

12. Meunier, N.; Briand, L.; Jacquin-Piques, A.; Brondel, L.; Pénicaud, L. COVID 19-Induced Smell and Taste Impairments: Putative Impact on Physiology. Front. Physiol. 2020, 11, 625110. [CrossRef] [PubMed]

13. Urata, S.; Maruyama, J.; Kishimoto-Urata, M.; Sattler, R.A.; Cook, R.; Lin, N.; Yamasoba, T.; Makishima, T.; Paessler, S. Regeneration Profiles of Olfactory Epithelium after SARS-CoV-2 Infection in Golden Syrian Hamsters. ACS Chem. Neurosci. 2021, 12, 589-595. [CrossRef] [PubMed]

14. Wang, Z.; Zhou, J.; Marshall, B.; Rekaya, R.; Ye, K.; Liu, H.X. SARS-CoV-2 Receptor ACE2 Is Enriched in a Subpopulation of Mouse Tongue Epithelial Cells in Nongustatory Papillae but Not in Taste Buds or Embryonic Oral Epithelium. ACS Pharmacol. Transl. Sci. 2020, 3, 749-758. [CrossRef]

15. Brandão, T.B.; Gueiros, L.A.; Melo, T.S.; Prado-Ribeiro, A.C.; Nesrallah, A.; Prado, G.V.B.; Santos-Silva, A.R.; Migliorati, C.A. Oral lesions in patients with SARS-CoV-2 infection: Could the oral cavity be a target organ? Oral Surg. Oral Med. Oral Pathol. Oral Radiol. 2020, 131, e45-e51. [CrossRef] [PubMed]

16. Sawa, Y.; Ibaragi, S.; Okui, T.; Yamashita, J.; Ikebe, T.; Harada, H. Expression of SARS-CoV-2 entry factors in human oral tissue. J. Anat. 2021, 238, 1341-1354. [CrossRef] [PubMed]

17. Liu, L.; Wei, Q.; Alvarez, X.; Wang, H.; Du, Y.; Zhu, H.; Jiang, H.; Zhou, J.; Lam, P.; Zhang, L.; et al. Epithelial cells lining salivary gland ducts are early target cells of severe acute respiratory syndrome coronavirus infection in the upper respiratory tracts of rhesus macaques. J. Virol. 2011, 85, 4025-4030. [CrossRef]

18. Manzalawi, R.; Alhmamey, K.; Abdelrasoul, M. Gingival bleeding associated with COVID-19 infection. Clin. Case Rep. 2020, 9, 294-297. [CrossRef]

19. Santos, C.F.; Morandini, A.C.; Dionísio, T.J.; Faria, F.A.; Lima, M.C.; Figueiredo, C.M.; Colombini-Ishikiriama, B.L.; Sipert, C.R.; Maciel, R.P.; Akashi, A.P.; et al. Functional Local Renin-Angiotensin System in Human and Rat Periodontal Tissue. PLoS ONE 2015, 10, e0134601. [CrossRef]

20. Hussain, M.; Jabeen, N.; Raza, F.; Shabbir, S.; Baig, A.A.; Amanullah, A.; Aziz, B. Structural variations in human ACE2 may influence its binding with SARS-CoV-2 spike protein. J. Med. Virol. 2020, 92, 1580-1586. [CrossRef]

21. Merk, A.; Bartesaghi, A.; Banerjee, S.; Falconieri, V.; Rao, P.; Davis, M.I.; Pragani, R.; Boxer, M.B.; Earl, L.A.; Milne, J.L.S.; et al. Breaking Cryo-EM Resolution Barriers to Facilitate Drug Discovery. Cell 2016, 165, 1698-1707. [CrossRef] [PubMed]

22. Aebersold, R.; Mann, M. Mass-spectrometric exploration of proteome structure and function. Nature 2016, 537, 347-355. [CrossRef] [PubMed]

23. Lechien, J.R.; Radulesco, T.; Calvo-Henriquez, C.; Chiesa-Estomba, C.M.; Hans, S.; Barillari, M.R.; Cammaroto, G.; Descamps, G.; Hsieh, J.; Vaira, L.; et al. ACE2 \& TMPRSS2 Expressions in Head \& Neck Tissues: A Systematic Review. Head Neck Pathol. 2021, 15, 225-235. [CrossRef]

24. Hoffmann, M.; Kleine-Weber, H.; Schroeder, S.; Krüger, N.; Herrler, T.; Erichsen, S.; Schiergens, T.S.; Herrler, G.; Wu, N.H.; Nitsche, A.; et al. SARS-CoV-2 Cell Entry Depends on ACE2 and TMPRSS2 and Is Blocked by a Clinically Proven Protease Inhibitor. Cell 2020, 181, 271-280.e8. [CrossRef]

25. Li, M.Y.; Li, L.; Zhang, Y.; Wang, X.S. Expression of the SARS-CoV-2 cell receptor gene ACE2 in a wide variety of human tissues. Infect. Dis. Poverty 2020, 9, 45. [CrossRef] [PubMed] 